\title{
POST-SOVIET TRANSITION: CENTRAL ASIA AND MONGOLIA
}

\section{By M.Orhon (Mongolia)}

The term "transitional countries" is widely used to refer to former socialist countries that have embarked on political, economic, social and institutional changes in the aftermath of the Soviet Union's collapse. The post-Soviet transition of the newly independent states of Central Asia and Mongolia has meant shifting from one coherent system to another, in an often radically different form. Although these countries are often lumped into a similar model, each state has pursued different paths, acting and reacting in its own ways. Domestically, the transition process has also meant a sudden realization of the political and economic effects of Marxist praxis. The dramatic "change of course" did not always gain popular sentiment, reinforcing the proposition that political culture cannot be imported. Without taking cultural, demographic, and geopolitical peculiarities into consideration, it has been impossible to simply imitate others. Although the intent, planning, and policies have maintained a persistently benevolent theme, they have brought an equally disturbing challenge to local traditions.

This paper will (1) comparatively analyse the peculiarity of each political economy and political culture upon jump-starting their transitions, (2) examine current transitional policies, and (3) provide a brief discussion of the future for both the regional states and Mongolia.

\section{MAPPING OF CENTRAL ASIA AND RELEVANCE OF MONGOLIA TO THE REGION}

Central Asia is made up of five former Soviet republics (Kazakhstan, Kyrgyzstan, Tajikistan, Turkmenistan and Uzbekistan) with a land area of nearly 4,500 kilometers, stretching from east to west. The borders of these newly independent states were determined by Moscow between 1924 and 1936 in relation to the political and economical considerations of the day, and these boundaries remained when the Soviet Union dissolved in late 1991. Peoples of Central Asia have experienced various historical turning points. In the recent history of the republics, Roy calls 1924 the founding act of the countries in Central Asia. " 1924 saw the dissolution of all the preceding administrative

${ }^{1}$ Olivier Roy, The New Central Asia. The Creation of Nations. (New York University Press, 2000), p. 61. 
entities and a complete rewriting of the map of Central Asia, on the basis of 'one ethnic group, one territory'."' Under the consolidation of the division of the newly created nation based on union of the Soviet Socialist Federation of Russia and the Soviet Socialist Republics, the Central Asian republics were subsequently born. ${ }^{3}$ However, it was not until 1936 when the territorial framework of the five republics was finally carved into permanent existence, which incidentally remained trapping the present topography of the region.

Historically, "[t]he imprint the Mongol conquest set on Central Asian society was more powerful than that of the Russians and Soviets." 4 The Mongolian empire certainly led to intermixing of populations within the region and beyond. It is said that "[a]11 the dynasties following Mongols in Central Asia (Timurids, Uzbeks and Moghuls) claimed descent from Genghis [Chinggis in Mongolian version] Khan." In his comprehensive narrative on Chinggis Khan's Legacy, Mc. Chesney notes that [i]n order to comprehend the ascendancy of legitimate political communities in Central Asia, one must begin with Chingiz (Chinggis) Khan, whose influence on the political culture of Central Asia (and even on Russia itself) should not be underestimated." In addition to the historical significance, the recent history of Mongolia and its several decades of statehood as an independent state compared to the newly independent states of Central Asia should not be neglected.

Mongolia, compared to the newly independent states of Central Asia, had decades of history as an independent state. Having gained its independence in 1924 and joined the United Nations in 1961, Mongolia has carved itself a symbolic panoply of an independent state (at least superficial codes of conventional statehood including well-defined national borders, national constitution, flag, anthem, and diplomatic ties). Therefore, its role as an independent state for several decades could offer lessons to the newly emerging states.

Furthermore, as illustrated in Table 1, geopolitically, Mongolia enjoys the potential to build bridges between the predominately landlocked (though the Kazakhstan and Turkmenistan border with the Caspian Sea is an inland waterway with limited transportation value) Central Asian countries and East

\footnotetext{
${ }^{2}$ Roy, The New Central Asia: The Creations of New Nations, p. 61.

${ }^{3}$ For more detailed information of "birth" of the republics see, Roy, 2000, p. 61.

${ }^{4}$ Martha B. Odcoll, "Central Asia: Common legacies and conflicts “ in, Roy Allison and Lena Jonson, eds. 2001. Central Asian Security: The New International Context, (Royal Institute of International Affairs), p. 28.

${ }^{5}$ Roy, The New Central Asia. The Creation of Nations. p. 6.

${ }^{6}$ R.D. Mc.Chesney, Central Asia: Foundations of Change. (The Darwin Press, Inc. Princeton, New Jersey: 1996), pp. 121-22.
} 
Asia. Mongolia is separated from the region by 67 kilometres east of Kazakhstan where ethnic Kazakhs comprise the majority of the population. Aligned with the Northeast Asian region, Mongolia's relations with East Asian states Japan, China and Korea may serve the CAS as a passageway to broaden their network of relations with the region and as a corridor for trade routes for both regions to penetrate their markets.

Table 1

Equally important, although Mongolia did not entirely belong to the homo sovieticus of the USSR, the shadow of the empire did go around Mongolia. In Mongolia, the model of statehood was implanted within the framework of the Soviet Union with the behind the scenes Soviet political tutelage and the entanglement of a dictatorial political system. Administrative, cultural, and political structures were embroidered through the mill of the Soviet machinery.

\section{POLITICAL RIPENESS OR UNEXPECTED STALEMATE}

Given the intensity of the Soviet influence both on Central Asia and Mongolia, the break-up of the Soviet Union unequivocally marked the modern history of the countries. This historic event encapsulated a political impetus for Mongolia to rebuild its nation-state in a unpaved path and for the Central Asian republics to assert (alas reassert) their independence and identity. ${ }^{9}$ Incidentally, like any unprepared civil societal reaction, political turmoil took place in Central Asia and Mongolia.

${ }^{7}$ Source: World Development Report 2002: Building Institutions for Markets. The World Bank. Washington, D.C., October 2002, pp. 232-33.

${ }^{8}$ The World Bank, 2001. 2001 World Development Indicators, Washington D.C.: Development Data Center, pp.12-14.

${ }^{9}$ Tsarist Russia began its dominance of these republics back in the 1850 s and the domination continued for 70 years under the Soviet system. 
Such a transition was entirely new not only in the case of Mongolia but for the former socialist countries as a whole including all the Central Asian states. This political vacuum urged the peoples to re-visit the political and economic effects of Marxist praxis and communist psyches in which they had been systematically indoctrinated for decades. This vacuum also encouraged them to find a way to carve out their statehood in a fashion that would be better off than their exiting societies.

By no means, has it been a simple task. First of all, there was no single model or process of transition that could be followed and replicated, which explains why the differences among transitional countries are as great, if not greater, than the similarities. It could be argued that the overall direction of the desired change may have been toward a Western-type democratic and free market-oriented governance or at least one preferred by the international community. However, during the transition years each country experienced unexpected surprises resulting from the impacts of internal and external shocks.

Secondly, most of the transitional states (especially the former Soviet republics, and Mongolia to somewhat lesser degree) heavily depended on the former Soviet Union and the Council for Mutual Economic Assistance (CMEA). Thus the abolition of this economic and technical assistance has negatively impacted each country.

Thirdly, many of the transitional states were the bi-products of the dissolution of the Soviet Union, including the Central Asian states. For those countries, the 1991 coup not only marked the collapse of communist rule within the Soviet Union but also hallmarked the disintegration of the Federation with the subsequent independence for respective states. "The natural inclinations of the rulers of the new states that joined the Russian-led Commonwealth of Independent States were to maintain close alignments with and to continue to depend on the former metropolitan center, now represented by the new Russian state." 10

Finally, the transitional states have been lumped together as post-Soviet transitional states, or more generally the communist bloc, which undermines the peculiarity of each country's reaction and evolution in midst of the process. Regardless, this transitional epoch urged each country to react and to battle its way outside the chaos, shocks, and stalemate.

\footnotetext{
${ }^{10}$ Roy Alison and Lena Jonson, (eds.). Central Asian Security: The New International Context. (Royal Institute of International Affairs, 2001), p.1.
} 


\section{Action or Reaction?}

In the case of Mongolia, for the first time (at least for seven decades until the 1990s) ${ }^{11}$ Mongolian civil society formed different political groupings. These included, in various forms, groups, unions and parties, even those radically opposed to the former party (which would have been unheard of just months earlier). They organized meetings, demonstrations and even a hunger strike. Realizing the degree of instability in the country that could trigger political chaos or even civil war, the entire Political Bureau and Secretariat of the Mongolian People's Revolutionary Party (MPRP) resigned making room for unprecedented change. The constitution was consequently amended in May 1992, introducing new electoral laws and legislation for political parties. ${ }^{12}$ This gave birth to Mongolia's first free election in 1992. From then on, the country embarked on a radical transformation with changes in almost every aspect of life.

As for the Central Asian states, it was the time that each newly born state had to test their independence and sovereignty. It was a rather unexpected and traumatic event for the history of all the states in the region. As McChesney observes "[f]rom a politically quiet and submissive role within the former Soviet Union, each of the republics was, without warning or preparation, forced to assume full responsibility for political organization, economic policies, and the well-being of its citizens." "Unlike most other former Soviet republics such as the Baltic republics and Ukraine, independence of CA republics was not the result of long and widespread mass movements and anti-government activities demanding fundamental changes." 14 No republic experienced any significant independence or pro-democracy movements; therefore, their independence came more as a surprise (hopefully pleasant), than hard-earned sovereignty.

In the years of independence, Central Asia (except Tajikistan) enjoyed relative political stability. This, however, could be undermined by the potential turmoil exacerbated by economic collapse and/or wider regional instability. Three regional countries border Afghanistan, whose security is increasingly threatened by the spill over from the Afghan conflict. Also, three out of five republics, Kazakhstan, Kyrgyzstan and Tajikistan, border China's Xinjiang

\footnotetext{
${ }^{11}$ Both Central Asian republics and Mongolia have had a history of kinship and tribal divisions.

${ }^{12}$ Frederick Nixson I. and Bernard Walters B., The Transition to a Market Economy: Mongolia 19901998. International Journal of Economic Development Vol.2, no. 1, 2000: pp. 35-66, p. 42.

${ }^{13}$ R.D. McChesney, Central Asia: Foundations of Change, p. 3.

${ }^{14}$ Hoomon Peimani, Failed Transition, Bleak Future: War and Instability in Central Asia and the Caucasus, (Praeger, Publishers, Westport, 2002), p. 41.
} 
province where political instability has been on the horizon for almost a decade. In Xinjiang, ethnic Turkic people comprise the majority of the population, and their ethnic impulse and nationalist sentiment (which is more Turkic than Sino) may trigger the rise of mass political dissent fuelled by poor economic performance and increasing social, political, and economic problems. "[T]he independence of their CA neighbors served as a catalyst and further encouraged their nationalist sentiments." 15 "Especially since the fall of the Soviet Union, they have resorted to a variety of anti-Chinese political activities demanding either independence or reunification with their kin in Kazakhstan."16

Equally serious, given the countries of the region evolved in and diverged from the former Soviet Union, regional security and stability is deeply contingent on the role that Russia plays. Certainly, despite its current weakness, Russia remains a dominant power among the former Soviet puppet states (for it possesses the largest population, highest GNP, and strongest military, including a nuclear arsenal) and is still perfectly capable of spinning the present situation in any direction. However, while the external situation has not been in the best interest of regional security, internal political conditions of the given countries have not stabilized either.

\section{Governance: Rule of the Game}

As can be seen in Table 2, the countries of Central Asia have carved out the necessary artifacts of their nation-state such as executive, legislative, and judicial bodies.

Table 2

\begin{tabular}{|c|c|c|c|c|c|}
\hline & $\begin{array}{l}\text { Date of } \\
\text { Independence }\end{array}$ & Constitution & Executives & Legislature & Judiciary \\
\hline Kazakhstan & $\begin{array}{l}\text { December } \\
16,1991\end{array}$ & 1995 & $\begin{array}{l}\text { President Nazarbayev; since 1991; } \\
\text { reelected January } 1999,79.8 \%\end{array}$ & $\begin{array}{l}\text { Bicameral: } \\
\text { Assembly, } \\
\text { Senate }\end{array}$ & $\begin{array}{l}\text { Supreme Court, } \\
\text { Constitutional } \\
\text { Council }\end{array}$ \\
\hline Kyrgystan & $\begin{array}{l}\text { August 31, } \\
1991\end{array}$ & $\begin{array}{l}1993 / \\
1996\end{array}$ & $\begin{array}{l}\text { President A .Akayev; initially } \\
\text { directly elected in } 1990 \text {, reelected } \\
\text { October } 2000,74 \%\end{array}$ & $\begin{array}{l}\text { Bicameral: } \\
\text { Legislative } \\
\text { Assembly; } \\
\text { Peoples } \\
\text { Representative } \\
\text { Assembly }\end{array}$ & $\begin{array}{l}\text { Supreme Court, } \\
\text { Constitutional } \\
\text { Court, Higher } \\
\text { Court of } \\
\text { Arbitration }\end{array}$ \\
\hline Tajikistan & $\begin{array}{l}\text { September } \\
9,1991\end{array}$ & 1994 & $\begin{array}{l}\text { President E Rahmonov; initially } \\
\text { elected in } 1992 \text {; reelected November } \\
1999,97 \%\end{array}$ & $\begin{array}{l}\text { Bicameral: } \\
\text { Assembly of } \\
\text { Representatives; } \\
\text { the National } \\
\text { Assembly }\end{array}$ & Supreme Court \\
\hline
\end{tabular}

\footnotetext{
${ }^{15}$ Peimani, 2002, p. 79

16 Ibid.
} 


\begin{tabular}{|c|c|c|c|c|c|}
\hline Turkmenistan & $\begin{array}{l}\text { October 27, } \\
1991\end{array}$ & 1992 & $\begin{array}{l}\text { President and Chairman of the } \\
\text { Cabinet of Ministers S. Niyazov; } \\
\text { since 1990, reelected } 1992,95.5 \% \\
\text { without opposition, unanimously } \\
\text { approved as president for life by the } \\
\text { legislature December } 1999\end{array}$ & $\begin{array}{l}\text { Unicameral: } \\
\text { Majlis }\end{array}$ & Supreme Court \\
\hline Uzbekistan & $\begin{array}{l}\text { September } \\
1,1991\end{array}$ & 1992 & $\begin{array}{l}\text { President I. Karimov; initially } \\
\text { gained power in } 1990 \text { as first } \\
\text { secretary of the Communist Party } \\
\text { under the Soviet system, reelected } \\
\text { January } 2000,92 \%\end{array}$ & $\begin{array}{l}\text { Unicameral: } \\
\text { National } \\
\text { Assembly }\end{array}$ & Supreme Court \\
\hline Mongolia & $\begin{array}{l}\text { November } \\
26,1921\end{array}$ & $\begin{array}{l}1924 \\
1940 \\
1960 \\
1992\end{array}$ & $\begin{array}{l}\text { President N. Bagabandi, initially } \\
\text { directly elected in 1997; reelected } \\
\text { May } 200158 \% \\
\text { Prime Minister N. Enkhbayar } \\
\text { selected by National Assembly, July } \\
2000\end{array}$ & $\begin{array}{l}\text { Unicameral: The } \\
\text { Great Hural }\end{array}$ & Supreme Court \\
\hline
\end{tabular}

Source: Extracted from Polity IV Project: Political Regime Characteristics and Transitions, 1800-2000 prepared by Monty G. Marshall and Keith Jaggers et al. Website: http:// www.cidem.umd.edu/inscr/polity/

The Central Asian republics and Mongolia initially saw a significant portion of political, economic, military leadership among the ex-communist elites. This has been clearly the case in all Central Asian republics including Kyrgyzstan, where "the gradual monopolization of political and economic power within the hands of President Askar Akaev and his closed circle of allies, and on the other, the expanding corruption within the ruling elite, the government, and the civil service." ${ }^{17}$ So, this growing authoritarianism in what was once the most democratic CA country, has resulted in "increasing restrictions on the activities of political parties and on individual freedoms and rights have paved the way for future eruption of popular dissatisfaction." 18

\section{Figure 1}

Authority Trends, 1990-2000
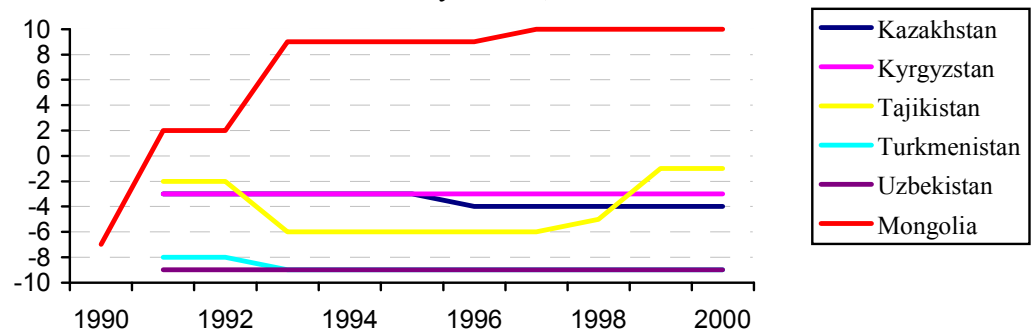

Source: Polity IV Project: Political Regime Characteristics and Transitions, 1800-2000, prepared by Monty G. Marshall and Keith Jaggers et al. Website: http://www.cidcm.umd.edu/ inscr/polity/

\footnotetext{
${ }^{17}$ Peimani, 2002, p. 49.

${ }^{18}$ Ibid., p. 50.
} 
In terms of the type of governance, in the decade of their independence and subsequent promulgation of their constitutions, a rising authoritarian type of governance has been observed in the region. Figure 1 (the vertical axis registers democracy scales with 10 representing the highest democracy score) depicts authority trends in the region over the past decade. It clearly shows that the region on the whole demonstrates a highly authoritarian type of governance with each state consistently below zero on the scale of 0-10. Even Kazakhstan and Kyrgyzstan, which had initially appeared to opt for a democratic model of governance, have also lapsed into authoritarian leadership in the years of their transition. Furthermore, the trends show that Turkmenistan and Uzbekistan have been the most authoritarian states with the lowest democracy score ( 9 each for the last 8,9 consecutive years up to 2000). "Their governments have pursued a policy of zero tolerance toward any type of political activity outside the pro-government one"19 while any opposition movements have been contained.

The consistency of authoritarian leadership among the regional countries poses the question whether it was inevitable to embrace some sort of controlled ruling in the chaotic situations found in the immediate aftermath of the Soviet break-up. Rousseau contends in his Social Contract or Principles of Political Rights that " dictatorship works "when the state does not yet have sufficiently stable basis to be capable of sustaining itself by the strength of its constitution." 20 With a cauldron of potential turmoil, political instability and overall social chaos resulting from the destruction of the previous carefully made tapestry, Rousseau's hypothesis demonstrates that it may have been 'necessary' for some sort of authority to provide safety for their peoples. However, he also notes the importance of the limitations of such power. He warns that it is absolutely important to limit the duration of dictatorship, which has not been the case in the region.

Nevertheless, there is little sign, if at all, of any significant changes to this trend so far. Hyland notes that "everyone is equally entitled to rights of democratic participation; however, there are obligations incumbent on a society as a whole, and ultimately on the government of that society, to ensure the provision to everyone of all those conditions, economic, educational and cultural, necessary to render effective political participation possible for all." ${ }^{21}$

\footnotetext{
${ }^{19}$ Ibid., p. 65 .

${ }^{20}$ Ibid., p. 164.

${ }^{21}$ op cit. James L. Hyland, “Democratic Theory: The Philosophical Foundations.” (Manchester 1995, p. 105.
} 
On the contrary, Nau observes that "Asia's emerging democracies suffer from deficiencies in all three areas that support a democratic peace - peaceful rotation of opposing parties in power, divided and accountable institutions, and protection of civil liberties," 22 which have all attributed to the low democracy performance. The Soviet totalitarianism gave way to authoritarianism, and it is a matter of time whether it will evolve toward more democratic practices. ${ }^{23}$

In terms of political achievement, Mongolia has been by far the most democratic state compared with the Central Asian states with the highest overall ratings based on the Polity IV democracy ratings (see Table 3). "Unlike the neighboring lands in Russia, China, and Central Asia, Mongolia has not, since the establishment of a multi-party system, elected a government that condones gross human rights abuses." ${ }^{24}$ Rights to freedom of speech, religion, travel and political participation have generally been respected.

Table 3

Polity IV 2000

\begin{tabular}{lccc}
\hline & Polity & Democracy & Autocracy \\
\hline Kazakhstan & -4 & 1 & 5 \\
Kyrgyzstan & -3 & 1 & 4 \\
Tajikistan & -1 & 2 & 3 \\
Turkmenistan & -9 & 0 & 9 \\
Uzbekistan & -9 & 0 & 9 \\
Mongolia & 10 & 10 & 0 \\
\hline
\end{tabular}

Source: Monty G. Marshall and Keith Jagger, et al. Polity IV Project: Political Regime Characteristics and Transitions, 1800-2000: Website: http://www.cidcm.umd.edu/inscr/polity/

The Polity IV democracy rating is based on a Democracy Score (scale of 010, with 0 signifying low democracy) minus an Autocracy Score (scale of 0-10, with 0 signifying low autocracy). Although the measures are of questionable accuracy as they are based on the collation of subjective multi-variable questionnaire responses from 'political experts' in each country, even taking a best-case approach to the interpretation of these responses, the table clearly demonstrates that the region is a long way from fulfilling the criteria of democratic perpetual peace.

The figure below shows that the global democratisation has made significant progress while autocracy has been continually decreasing in recent years. However, despite this picture it is not yet inevitable that the Central Asian republics are about to embark on a course toward liberal democracy.

\footnotetext{
${ }^{22}$ op. cit. Henry Nau. "At Home Abroad: Identity and Power in American Foreign Policy ": (Ithica: Cornell University Press, 2002), p. 163.

${ }^{23}$ Ibid., p. 123.

${ }^{24}$ Morris Rossabi. Mongolia in the 1990s: from Commissars to Capitalists? http://www.eurasianet.org/ resource/mongolia/links/rossabi.html.
} 
Figure 2

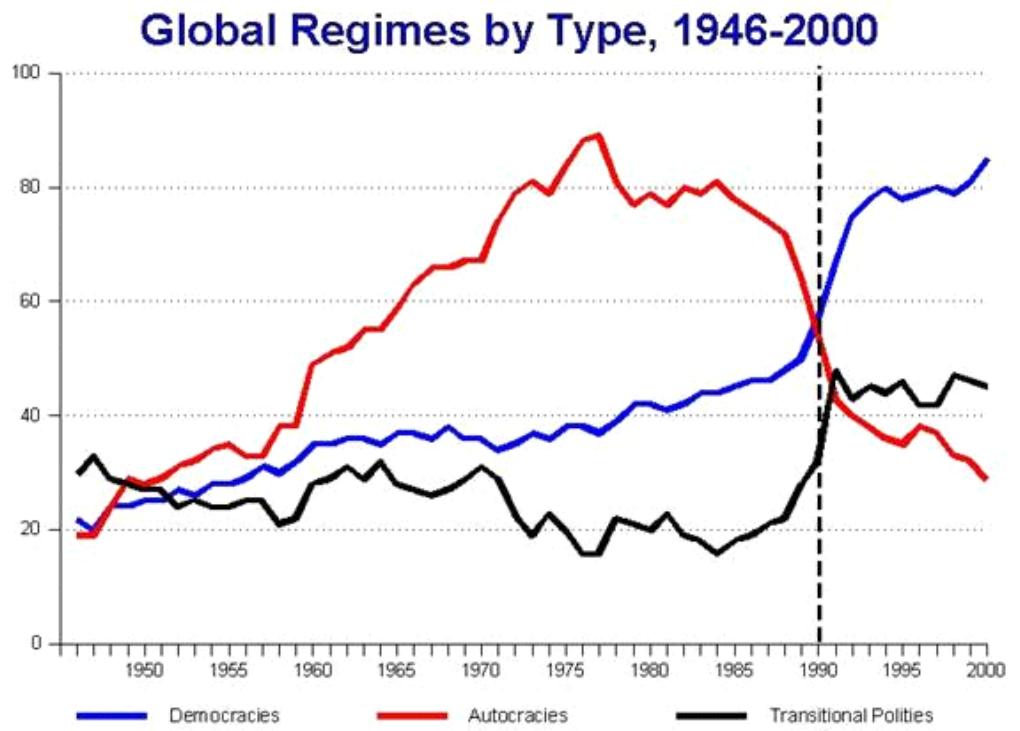

To the contrary, Samuel Huntington warns that "although there has been a wave of democratisation, such waves are usually followed by corresponding (if more limited) waves of counter-democratic authoritarianism, and that democratisation tends to follow a two-step-forward, one-step-back pattern." ${ }^{25}$ The transition of CAS and Mongolia have shown that not all transitions from authoritarian rule converge into democracy, and states undergoing a regime transition are at their most volatile, a danger to their own people and to their neighbors. Perhaps it suggests that this universalist or predominately Westerncentric liberal democratic model may not be the blueprint for other states and recipe for well-being of a society.

If democracy is not the ultimate (at least immediate) alternative for the transitional countries, what other options can the countries draw an example from? Nau notes that the lack of full protection of civil liberties in Asia "reflects the significantly different traditions regarding the relationship of the individual to society... [where] authority patterns 'infuse all social relationships-in the family (Confucianism), in the religion (Buddhism and Islam) and in the state

${ }^{25}$ Samuel P. Huntington, The Third Wave: Democratization in the Late Twentieth Century. (Norman: University of Oklahoma Press, 1991), p. 25. 
(Shintoism). ${ }^{26}$ Inherently, the Chinese model of transition has been the most distinct of all transitional states. China is and historically has always been a non-pluralistic society and its 'authoritarian shadow has been in tact with economic liberation.' Some argue that for its size and level of development, perhaps it is the right move. Whether it be authoritarian or democratic or something fundamentally different, elites of the states face the challenge to weave a social safety net for their citizens and "deal" with the post-Soviet legacy.

\section{Economic Venture}

Facing a new reality, the CA states, like all other former Soviet republics, opted to restructure their economies. They initiated economic reforms to replace the crumbling socialist economies with a type of a free-enterprise economy through decentralization and the creation of a strong private sector, though it has been somewhat confined to the service industry and small-scale industrial and agricultural enterprises. ${ }^{27}$

In terms of industrialization, the greatest per capita industrial output was in Kazakhstan (closely followed by Kyrgyzstan) and was lowest in Tajikistan. Generally, despite the Soviet policy in preceding decades, the whole region counted for the lowest level of per capita industrial output when compared to any of the other Soviet republics. By the Gorbachev period, the per capita industrial output of the region was less than half that of Russia. ${ }^{28}$ In addition, both in Central Asia and Mongolia a large proportion of the population remained pursuing agricultural ventures. Central Asia was therefore not only conspicuous by its much lower rate of industrialization, but also by the extremely low rates of urbanization of its titular nationalities. ${ }^{29}$

Generally external shocks account for much of the 'transitional shocks,' namely the disruption caused by the almost complete withdrawal of financial and technical assistance from the former Soviet Union and the abolition of the CMEA. It was an enormous challenge for the leaders of the states to establish and develop institutions suitable and necessary for such a traumatic process

\footnotetext{
${ }^{26} \mathrm{Nau}, 2002$, p. 153.

${ }^{27}$ What was generally common for the CAS was comparatively underdeveloped and backward compared to the European part of the Soviet Union. They were the poorest and the least industrialized among the satellite regions. Furthermore, all five republics heavily depended on central government assistance. For instance, Tajikistan had to rely on the central government for $80 \%$ of its fuel and $75 \%$ of its foodstuffs. Uzbekistan received 6.4 billion rubles from Moscow in 1990, 43\% of its total expenditures that year. This explains why transition was a great challenge for all the regional states. As was the case in Mongolia, the sudden withdrawal of Soviet assistance created a huge economic limbo in each state.

${ }^{28}$ Glenn, 1999, p. 95.

${ }^{29}$ Ibid.
} 
due to the unfamiliarity and unpreparedness of economic agents and political leaders. As a result the economies in transition in Central Asia and Mongolia were plunged into a long-lasting recession of five to six years.

Nevertheless, both CAS and Mongolia opted for changes in the economic dimension. The formation of a market economy, based on the price of liberalization, privatization of state properties, decollectivization of agricultural associations, and state farms was initiated in the region and Mongolia, with a varying degree and speed. In Mongolia, "[t]he institutions of a free market state, such as the central and commercial banks, and of the legal and other codes necessary to support the operation of a market economy were created subsequently. ${ }^{30}$

The Asian Development Bank reports that despite the unfavourable external circumstances, the majority of countries continued the process of economic recovery that had been under way for the three preceding years. ${ }^{31}$ Weighted average GDP growth in the sub region was $8.7 \%$ in 2000 and $10.7 \%$ in 2001. (See Table 4)

Table 4

Selected Economic Indicators

\begin{tabular}{l|lllllll}
\hline & $\mathbf{1 9 9 9}$ & $\mathbf{2 0 0 0}$ & $\mathbf{2 0 0 1}$ & \multicolumn{2}{c}{ 2002 } & \multicolumn{2}{c}{ 2003 } \\
\hline GDP Growth (\%) & & & & ADO* & Update & ADO & Update \\
Average & 5.1 & 8.7 & 10.7 & 5.7 & 6.2 & 6.4 & 5.7 \\
Kazakhstan & 2.7 & 9.8 & 13.2 & 7.0 & 7.5 & 6.0 & 6.0 \\
Kyrgyzstan & 3.7 & 5.4 & 5.3 & 4.5 & 4.4 & 4.5 & 4.2 \\
Tajikistan & 3.7 & 8.3 & 10.3 & 6.0 & 8.0 & 5.0 & 6.0 \\
Turkmenistan & 16.0 & 17.6 & 20.5 & 11.0 & 11.0 & 11.0 & 11.0 \\
Uzbekistan & 4.4 & 4.0 & 4.5 & 4.0 & 2.0 & 5.0 & 3.0 \\
Inflation (\%) & & & & & & & \\
Average & 15.5 & 17.0 & 13.6 & 10.0 & 10.8 & 5.6 & 8.2 \\
Kazakhstan & 8.3 & 13.2 & 8.4 & 6.6 & 5.6 & 5.6 & 5.9 \\
Kyrgyzstan & 35.9 & 18.7 & 6.9 & 7.5 & 4.1 & 5.5 & 4.7 \\
Tajikistan & 27.5 & 32.9 & 38.6 & 8.0 & 13.0 & 7.6 & 11.0 \\
Turkmenistan & 23.5 & 7.4 & 5.6 & 8.5 & 8.5 & 7.5 & 7.5 \\
Uzbekistan & 26.0 & 28.2 & 26.4 & 18.0 & 22.5 & - & 13.5 \\
Current Account Balance $(\%$ of & & & & & & & \\
GDP) & & & & & & & \\
Average & -4.3 & -0.5 & -4.2 & -4.5 & -4.1 & -4.9 & -4.4 \\
Kazakhstan & -1.4 & 2.3 & -7.8 & -4.5 & -6.6 & -4.7 & -6.0 \\
Kyrgyzstan & -14.4 & -5.6 & -0.9 & -6.3 & -3.8 & -6.5 & -5.4 \\
Tajikistan & -3.4 & -6.6 & -7.0 & -6.2 & -4.2 & -5.5 & -4.5 \\
Turkmenistan & -18.0 & -13.9 & -1.5 & - & - & - & - \\
Uzbekistan & -1.0 & 1.4 & -0.6 & - & -1.2 & - & -2.0 \\
\hline
\end{tabular}

Sources: Asian Development Outlook 2002 update: Central Asia http://www.adb.org/ documents/books/ado/2002/Update/central_asia.pdf. *Staff estimates

\footnotetext{
${ }^{30}$ Nixson and Walters, 1996, p. 40.

${ }^{31}$ Asian Development Outlook 2002 Update: Central Asia http://www.adb.org/documents/books/ado/2002/ Update/central_asia.pdf
} 
All the republics and Mongolia have embarked on the road to privatization at varying speeds. Some (especially Uzbekistan, Turkmenistan and Tajikistan) have taken a gradual approach to reform, and others chose more rapid liberalization and privatization. In each case, privatization has been a key element in the 'reform' program. In Mongolia, after the initial steps of price liberalization, the privatization process started immediately with enactment of the "Privatization Law of Mongolian People's Republic" starting with the privatization of 44 percent of state property through vouchers issued to every citizen of the country. However, this process was strongly flayed (perhaps fairly) for its mismanagement, inefficiency, and corruption. Nevertheless, these factors further enhanced market relations, allocation of capital, and the degree of the open market economy.

For countries of Central Asia and Mongolia, Foreign Direct Investment (FDI) has been an important and necessary component of economic change due to their shortage of capital for investment. Each country has taken a variety of measures to stimulate investment, especially as required by the investors such as the restoration and maintenance of macroeconomic and financial stability. However, the degree and scope of implementation of these measures have again varied from country to country.

\section{Table 5}

Foreign Direct Investment

\begin{tabular}{|c|c|c|c|c|c|c|c|}
\hline & & 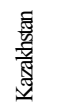 & $\begin{array}{l}\text { 苟 } \\
\text { 芴 }\end{array}$ & 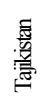 & 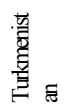 & 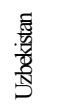 & 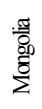 \\
\hline \multirow{2}{*}{$\begin{array}{l}\text { Gross } \\
\text { domestic } \\
\text { product }\end{array}$} & Millions of dollars (2000) & 18,264 & 1,304 & 987 & 4,404 & 13,517 & 975 \\
\hline & $\begin{array}{l}\text { Gross domestic product per capita } \\
\text { \%growth }(1999-2000)\end{array}$ & -4.6 & -4.1 & -1.7 & -4.8 & -0.5 & 1.0 \\
\hline \multicolumn{2}{|c|}{$\begin{array}{l}\text { Foreign direct investment (Millions of dollars } \\
\text { 1999) }\end{array}$} & 1,587 & 36 & 24 & 80 & 113 & 30 \\
\hline \multicolumn{2}{|c|}{ Official development assistance } & 11 & 55 & 20 & 4 & 5 & 92 \\
\hline \multirow{2}{*}{$\begin{array}{l}\text { Externa } \\
\text { I Debt }\end{array}$} & Total (Millions of dollars; 1999) & 5,764 & 1,699 & 889 & 2,015 & 4,573 & 891 \\
\hline & Present value (\% of GNI; 1999) & 38 & 105 & 66 & 52 & 25 & 59 \\
\hline
\end{tabular}

Source: World Development Report 2002: Building Institutions for Markets. The World Bank, Washington, D.C., October 2002.

Generally, because of the degree of potential political turmoil (the Tajik civil war, and possible spill-over to the regional states), relatively limited 
economic significance made less incentive for foreign aid and investment to the regional countries. From the respective states in Table 3, Kazakhstan remained by far the major recipient of FDI in 2001 receiving $\$ 1.2$ billion in 2000. On the other hand, for some FDI has not been as attractive. In Turkmenistan, FDI accounted for 9 percent of total investment in the first half of 2001 while FDI inflows fell in Kyrgyzstan by 20 percent.

\section{CONLCUSION}

As discussed in earlier sections, the current situation in these countries makes it hard to predict what the future holds for Mongolia and the Central Asian states. With respect to the economy, whether it will 'catch up' with developed market economies or remain ensconced in the developing world is just not predictable. Central Asia lacks a regional power whose leverage may affect it positively. In the case of East Asia, the phenomenal growth of Japan and its economic miracle has had an invaluable impact on the regional countries such as Korea, Taiwan, and other Southeast Asian economies. ${ }^{32}$ On the contrary, given that most regional countries are ranked far behind most of the world economies as shown in Table 6 and there is no country in the region whose development can be replicated, creating hierarchical networks of production as has been the case in East Asia.

Table 6

Rankings of economies based on GNI per capita

\begin{tabular}{lccc}
\hline $\begin{array}{l}\text { GNI per capita, } \\
\text { 2000 World Bank Atlas Method }\end{array}$ & Global Rankings & $\begin{array}{c}\text { Regional } \\
\text { rankings }\end{array}$ & $\begin{array}{c}\text { GNI per } \\
\text { capita 2000 }\end{array}$ \\
\hline Kazakhstan & 125 & 1 & 1,260 \\
Kyrgyzstan & 184 & 5 & 270 \\
Tajikistan & 197 & 6 & 180 \\
Turkmenistan & 143 & 2 & 750 \\
Uzbekistan & 171 & 4 & 360 \\
Mongolia & 164 & 3 & 390 \\
\hline
\end{tabular}

Source: 2002 World Bank Atlas. World Bank Development Data Group.

Washington, D.C., 2002. p. 19.

The political situation is far from stable or sustainable. For the past decade, the countries have seen a creation of political parties that ultimately evolved

32 "Flying Geese" analogy is quite often used to describe the regional phenomenal growth. The analogy, proposed by the Japanese economist Akamatu Kaname, suggests that the diffusion of manufacturing in East Asia has been characterized by shifting hierarchical networks of production, replicating Japan's development experience in country after country. 
into a professional class of politician or an entrenched elite oligarchy. The countries further need to enhance freedom of the press and information, to reduce inequality of resources, greater accountability of non-elected individuals and organization, decentralization of decision-making, and most importantly, better education of all citizens, bearing in mind that incompetence could be the result of lack of opportunity for responsible involvement rather than a justification for permanent denial of such opportunity. ${ }^{33}$

What is clear, however, is that the peoples of the republics and Mongolia have paid a heavy price during their transition from their previous totalitarian state to an alien unpredictable forms of governance. The questions remain as to how to achieve greater material prosperity without jeopardizing the security of sufficient political stability. Other Asian countries have painfully shown that economic prosperity is difficult to achieve without sacrificing their culture, traditions, values and ways of life. Currently, the countries are in a state of uncertainty making it difficult to predict what the future holds for both Central Asia and Mongolia.

\section{References}

Alison, Roy and Lena Jonson, (eds.) 2001. Central Asian Security: The New International Context . Royal Institute of International Affairs.

Arendt, H. The Origins of Totalitarianism, in Mitchell Cohen and Nicole Fermon (eds.), 1996. Princeton Readings in Political Thought: Essential Texts since Plato: Princeton University of Press

Asian Development Outlook 2002 update: Central Asia http:// www.adb.org/documents/books/ado/2002/Update/central_asia.pdf

Central Intelligence Agency, December 2000. Global Trends 2015: A Dialogue about the Future with Nongovernmental Experts. http://www.cia.gov/ cia/publications/globaltrends2015/375953.gif

Dahl, Robert, 1989. Democracy and Its Crisis. Yale.

Glenn, John, 1999. The Soviet Legacy in Central Asia. Macmillan Press, Ltd., UK.

Huntington, S.P., 1991. The Third Wave: Democratization in the Late Twentieth Century. Norman: University of Oklahoma Press.

Hyland, James L., 1995. Democratic Theory: The Philosophical Foundations. Manchester

${ }^{33}$ Op. cit. Hyland, 1995. pp. 256-7. 
Marshall, Monty G. and Keith Jaggers, et al. Polity IV Project: Political Regime Characteristics and Transitions, 1800-2000:

Website: http://www.cidem.umd.edu/inscr/polity

Nau, Henry R., 2002. At Home Abroad: Identity and Power in American Foreign Policy: Ithica: Cornell University Press.

Nixson, Frederick I. and Bernard Walters B., 2000. "The Transition to a Market Economy: Mongolia 1990-1998." International Journal of Economic Development 2(1), 2000: pp. 35-66.

Odcoll, Martha B. "Central Asia: Common legacies and conflicts" in Allison, Roy and Lena Jonson eds., 2001. Central Asian Security: The New International Context.

Peimani, Hoomon, 2002. Failed Transition, Bleak Future: War and Instability in Central Asia and the Caucasus. Praeger Publishers: Westport.

Pridham, Geoffrey (ed.), 1991. Encouraging Democracy: The International Context of Regime Transition in Southern Europe. New York: St. Martin's Press.

Rossabi, Morris. Mongolia in the 1990s: from Commissars to Capitalists? http://www.eurasianet.org/resource/mongolia/links/rossabi.html

Rousseau, Jean-Jacques. [1755] Discourse on Political Economy in Ritter, Alan and Julia Conaway Bondanella (eds.), 1988. Rousseau's Political Writings: Discourse on Inequality, Discourse on Political Economy and on Social Contract. Norton Critical Edition (1 ${ }^{\text {st }}$ edition).

Rousseau, Jean-Jacques. [1762] Social Contract, in Ritter, Alan and Julia Conaway Bondanell, (eds.) 1988. Rousseau's Political Writings: Discourse on Inequality, Discourse on Political Economy and on Social Contract. Norton Critical Edition ( $1^{\text {st }}$ edition).

Roy, Olivier, 2000. The New Central Asia. The Creation of Nations. N.Y.: New York University Press.

Stychin. Carl F., 1998. A Nation by Rights: National Cultures, Sexual Identity Politics and the Discourse of Rights. Philadelphia: Temple University Press.

The World Bank, 2001.2001 World Development Indicators, Washington, D.C.: Development Data Center.

2002 World Bank Atlas. World Bank Development Data Group. Washington, D.C., 2002.

World Development Report 2002: Building Institutions for Markets. The World Bank, Washington, D.C., October 2002. 